Journal of

Business and Strategic

Management

(JBSM)

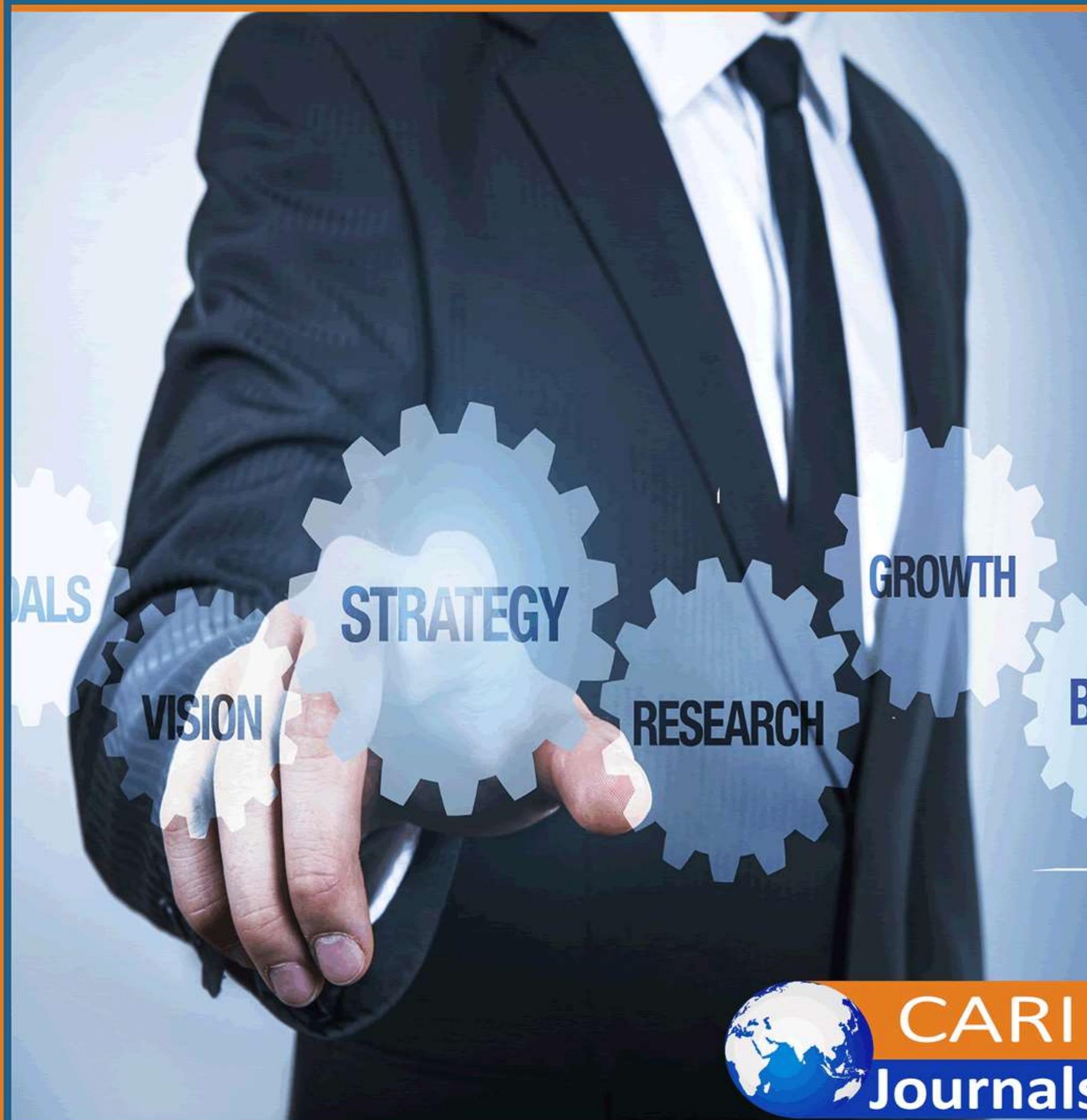




\title{
EFFECT OF TECHNOLOGICAL ADOPTION STRATEGY ON THE PERFORMANCE OF SACCOS IN KENYA
}

\author{
1*Paul Wambua Kavulya \\ Post Graduate Student: School of Business \\ Jomo Kenyatta University of Agriculture and Technology \\ *Author's E-mail: pkwambua292@gmail.com \\ ${ }^{2}$ Prof. Willy Muturi $\&{ }^{3}$ Dr. Gladys Rotich \\ Lecturers, School of Business \\ Jomo Kenyatta University of Agriculture and Technology \\ ${ }^{4}$ Dr. Kennedy Ogollah \\ Lecturer, School of Business \\ University of Nairobi
}

\begin{abstract}
Purpose: To examine the effect of technological adoption strategy on the Performance of SACCOs in Kenya

Methodology: The study was a cross-sectional survey with a descriptive research design. This design is appropriate because it is considered suitable for gathering information and generating appropriate conclusions with respect to the research questions. The target population of this study was the 181 authorized deposit taking SACCOs in Kenya that have been in existence for at least the last 5 years SASRA (2014). The firms which have been there for 5 years are considered to have adequate knowledge and have deposit mobilization strategies in place. The number of respondents was 181 CEOs and Business development managers, who are in charge of strategies. The study used questionnaires as the main data collection instrument that contained both open and closed ended questions. Questionnaires were preferred because they are effective data collection instruments that allow respondents to give much of their opinions pertaining to the research problem. Primary data was collected through administering of questionnaires to Members of the SACCOs, senior staff of the SACCOs and Cooperative Ministry/regulatory officials. The study employed descriptive analysis technique on the collected data. Multiple regression analysis was used to establish the relationship between the dependent and independent variables. Results were presented using frequency tables and figures.
\end{abstract}

Results: Correlation analysis showed that technological adoption strategy and performance of Saccos are positively and significantly associated. Regression analysis indicated that technological adoption strategy has a positive and significant effect on performance of Saccos in Kenya. The hypotheses results indicated that there is a significant relationship between technological adoption strategy and performance of Saccos in Kenya. 
Unique contribution to theory, practice and policy: From the study findings, it was recommended that Saccos should lay out procedures and strategies such as product innovation, market innovation, technological innovation and process innovation so as to enhance their penetration in the market. Further, the study recommended the need for the firms to invest in technological advancement by equipping their staff with technical skills and also providing them with the necessary facilities.

Keywords: technological adoption strategy, performance, SACCOs

\subsection{INTRODUCTION}

\subsection{Background of the Study}

The market share of cooperative finance was equivalent to 14 percent in 2004 (Hesse \& Cihak, 2007). Previous research on cooperative finance during crisis indicates that they tended to fare better than investor-owned savings and loans institutions, as they pursue more conservative investment policies (Chaddad \& Cook, 2004). For instance, analysis from the IMF indicates that cooperative banks in developed countries tend to be more stable than commercial banks, especially during financial crisis, as their investment patterns tend to be less speculative and returns are therefore less volatile (Hesse \& Cihak, 2007).

The growth of any economy depends on capital accumulation, which in turn depends on investment and an equivalent amount of savings to match it. Two key issues for developing countries are how to stimulate investment and increase the level of saving to fund increased investment (Olando, Jagongo, \& Mbewa, 2013).

Deposits mobilization should be backed by adequate institutional capital which ensures permanency, provide cushion to absorb losses and impairment of members' savings (Ogendo, 2012). The institutional capital, which comprises the core capital and less share capital, is mainly accumulated from appropriation of the surpluses. Therefore, SACCOs should strive to maximize on the earnings to build the institutional capital (Branch \& Cifunentes, 2001; Ombado, 2010). This institutional capital ensures the permanence and growth of the SACCOs even in turbulent economic times (Ogendo, 2012). In fact, it helps the SACCOs to grow and, remain economically and financially viable (Gijselinckx \& Devetere, 2007). Such growth is enhanced by effective financial practices.

Accordingly, the financial practice team identifies the most appropriate methods and structure of financing the SACCOs' assets. Such a structure should be in a position to optimize surpluses (Evans, 2001). More so, prudent funds allocation strategies is an important financial practice function in any SACCO society. This aspect usually involves decisions to commit the SACCOs' funds to planned investment options. SACCOs need to make decisions to invest their funds more efficiently in anticipation of expected flow of benefits in the long run. Such investment decisions generally include expansion, acquisition, modernization and replacement of long-term assets (Maina, 2007). Thus, the SACCOs' value is deemed to increase where the investments are profitable and add to the wealth in the long run. This situation is obtained where the SACCO involves itself with investments that yield benefits greater than the opportunity cost of capital. 


\subsection{Statement of the Problem}

Over time, SACCOs have been trying to address members' demands by mobilizing funds and granting credit to members. However, they have not been able to grow their wealth sufficiently through accumulation of enough institutional capital to finance non-withdraw able capital funded assets, provide cushion to absorb losses and impairment of members' deposits (GOK, 2011).

WOCCU (2008) showed that $38.3 \%$ of Kenyans are not included in financial services and use. The vision 2030 for financial services in Kenya can be fully achieved if SACCO members can transform their savings into viable investments. All these indicate low levels of deposits mobilization strategies and investment in Kenya. The problem of low deposits and investment comes at a time when African Confederation of Co-operative Savings and Credit Association workshop has classified SACCOs as vehicles for economic growth (ACCOSCA, 2011). Besides, the government of Kenya recognizes cooperatives as the major contributor to national development with the country's population of approximately 44 million (GOK, 2011). The competitive environment has also seen changes. The financial sector has been liberalized. Commercial banks offer salary loans while MFIs offer loans to small scale businessmen. These were traditionally markets dominated by SACCOs. SACCOs on the other hand have ventured into FOSA operations, funds transfers, salary processing. These were domains of commercial banks. Changes have also occurred in the information communication technology (ICT) world. All these changes together with others have led to the need for training and development for SACCO staff and board members.

Ademba, (2012) identifies SACCO strategies in seeking alternative funding sources key amongst them being strict requirements/bureaucracy at 33\%, inadequate government support at $29 \%$ and legal restrictions/SASRA regulations at $21 \%$, default risks/poor repayment at $51 \%$, inadequate funds to lend at $38 \%$ and securing loans i.e. guarantors/collateral at $23 \%$ and lack of proper legal framework at $23 \%$. Further, due to the high failure of SACCOs, it is estimated that less than $50 \%$ of the target SACCO enterprises are unable to meet their strategic objectives (Ademba, (2012).

Notably, most of the literature reviewed linking deposit mobilization strategies to organization performance are drawn from developed countries context like the USA, China and Sweden. For example, Zhang, Di Benedetto and Hoenig (2009) study assessed the interplay of product development strategy and performance in the context of Chinese subsidiaries of multinational companies. Karlsson and Tavassoli (2015) paper analyzes the effect of various innovation strategies of firms on their future performance, captured by labour productivity in Sweden. Kumar, Venkatesan and Reinartz (2008) evaluated the performance implications of adopting a customer-focused sales campaign in United States. These studies revealed contextual gap and hence cannot be generalized to Kenya.

Further, a few of the literature reviewed locally linking technological adoption strategy to organization performance presented conceptual, contextual and methodological gaps. For instance, Nyoike and Muturi (2015) assessed the factors affecting deposit mobilization by bank agents in Kenya, a case of National Bank of Kenya. The study employed a case study design thus presenting a methodological gap. Kamaamia (2015) study investigated the effect of marketing strategies on organizational performance at Mediamax Network Limited thus presenting a contextual gap. Mutegi (2018) assessed the role of innovation strategy on insurance penetration in Kenya, thus presenting a conceptual gap. 
The current study, therefore sought to address the existing research gaps by establishing the effect of technological adoption strategy on the performance of savings and credit cooperative societies in Kenya.

\subsection{Specific Objective}

To assess the effect of technological adoption strategy on the Performance of SACCOs in Kenya

\subsection{Research Question}

What is the effect of technological adoption strategy on the Performance of SACCOs in Kenya?

\subsection{LITERATURE REVIEW}

\subsection{Theoretical Review}

\subsubsection{Diffusion of Innovations Theory}

Diffusion of innovations is a theory postulated by Rogers (1962) has been used since the 1950s to describe the innovation-decision process. According to the innovation-decision process, an individual or decision making unit passes from first the knowledge of an innovation, then to forming an attitude toward the innovation to a decision to adopt or reject to implementation of the new idea and to confirmation of this decision.

Diffusion of innovations is a theory that seeks to explain how, why, and at what rate new ideas and technology spread through cultures. Rogers (2003), argues that diffusion is the process by which an innovation is communicated through certain channels over time among the participants in a social system. The origins of the diffusion of innovations theory are varied and span multiple disciplines. The four main elements of diffusion are the innovation, communication channels, time, and the social system. Diffusion is a special type of communication, in which the messages are concerned with a new idea. It is this newness of the idea in the message content of communication that gives diffusion its special character.

This process consists of a series of actions and choices over time through which an individual or an organization evaluates a new idea and decides whether or not to incorporate the new idea into ongoing practice. This behavior consists essentially of dealing with the uncertainty that is inherently involved in deciding about a new alternative to those previously in existence. It is the perceived newness of the innovation, and the uncertainty associated with this newness, that is a distinctive aspect of innovation decision making (Rogers, 2003).

This theory supports the third objective; to determine influence of technology innovation strategy on the performance of SACCO in Kenya. This theory is related to the study as it presents the process of newness and implementation of innovation. 


\subsection{Conceptual Framework}

\begin{tabular}{|c|c|}
\hline $\begin{array}{l}\text { Technological Innovation } \\
\text { Strategy }\end{array}$ & $\begin{array}{l}\text { Performance of Savings } \\
\text { and Credit Cooperatives }\end{array}$ \\
\hline $\begin{array}{ll}\text { - } & \text { Computerization of processes } \\
\text { - } & \text { Innovation capability } \\
\text { - } & \text { Internet facility }\end{array}$ & $\begin{array}{ll}\text { - } & \text { Profitability } \\
\text { - } & \text { Revenue } \\
\text { - } & \text { Net assets }\end{array}$ \\
\hline
\end{tabular}

Independent Variable

Dependent Variable

Figure 1: Conceptual Framework

\subsection{RESEARCH METHODOLOGY}

The study was a cross-sectional survey with a descriptive research design. This design is appropriate because it is considered suitable for gathering information and generating appropriate conclusions with respect to the research questions. The target population of this study was the 181 authorized deposit taking SACCOs in Kenya that have been in existence for at least the last 5 years SASRA (2014). The firms which have been there for 5 years are considered to have adequate knowledge and have deposit mobilization strategies in place. The number of respondents was 181 CEOs and Business development managers, who are in charge of strategies. The study used questionnaires as the main data collection instrument that contained both open and closed ended questions. Questionnaires were preferred because they are effective data collection instruments that allow respondents to give much of their opinions pertaining to the research problem. Primary data was collected through administering of questionnaires to Members of the SACCOs, senior staff of the SACCOs and Cooperative Ministry/regulatory officials. The study employed descriptive analysis technique on the collected data. Multiple regression analysis was used to establish the relationship between the dependent and independent variables. Results were presented using frequency tables and figures.

\subsection{RESEARCH FINDINGS AND DISCUSSION}

\subsection{Demographic Characteristics}

This section presents the descriptions of the respondents in terms of gender, age, marital status and level of academic education.

\subsubsection{Gender of the Respondents}

The respondents were asked to indicate their gender. Results in figure 2 revealed that majority of the respondents $(58.3 \%)$ were male while $41.7 \%$ of the respondents were female. The results imply that there is male dominance in the management of the Saccos. However, the gender composition in the Saccos meets the minimum constitutional threshold of 1/3. 


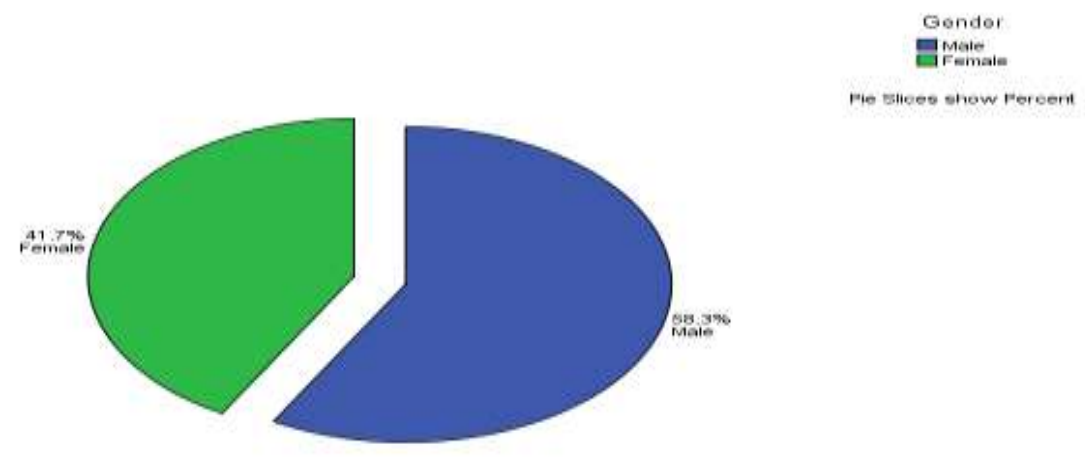

Figure 2: Gender of respondents

\subsubsection{Age of the Respondents}

The respondents were asked to indicate their age bracket. Results presented in table 4.3 revealed that $44.6 \%$ of the respondents indicated $41-50$ years, $20.7 \%$ indicated $31-40$ years, $19.4 \%$ indicated over 50 years, $12 \%$ indicated $21-30$ years while $3.3 \%$ I indicated below 21 years. The results imply that majority of the respondents were between the age of 31 and 50 years.

This implies that the management of the Saccos is headed by relatively young and energetic individuals. This is likely to have a significant impact on the organizations' ability to adopt effective deposit mobilization strategies.

Table 1: Age of the Respondents

\begin{tabular}{lcc}
\hline Responses & Frequency & Percent \\
\hline Below 21 years & 5 & $3.3 \%$ \\
$21-30$ years & 17 & $12.0 \%$ \\
$31-40$ years & 29 & $20.7 \%$ \\
$41-50$ years & 61 & $44.6 \%$ \\
Over 50 years & 26 & $19.4 \%$ \\
Total & $\mathbf{1 3 8}$ & $\mathbf{1 0 0}$ \\
\hline
\end{tabular}

\subsubsection{Marital Status of the Respondents}

The respondents were asked to indicate their marital status. Results in figure 3 showed that majority $(82.6 \%)$ of the respondents were married, $7.4 \%$ were single while $5 \%$ were divorced and widowed respectively. The results imply that majority of the respondents are married and therefore, are likely to be more responsible. This responsible behavior is expected to be reflected even in their performance at work. As such, married managers are expected to facilitate the improvement of the organizations' performance. 


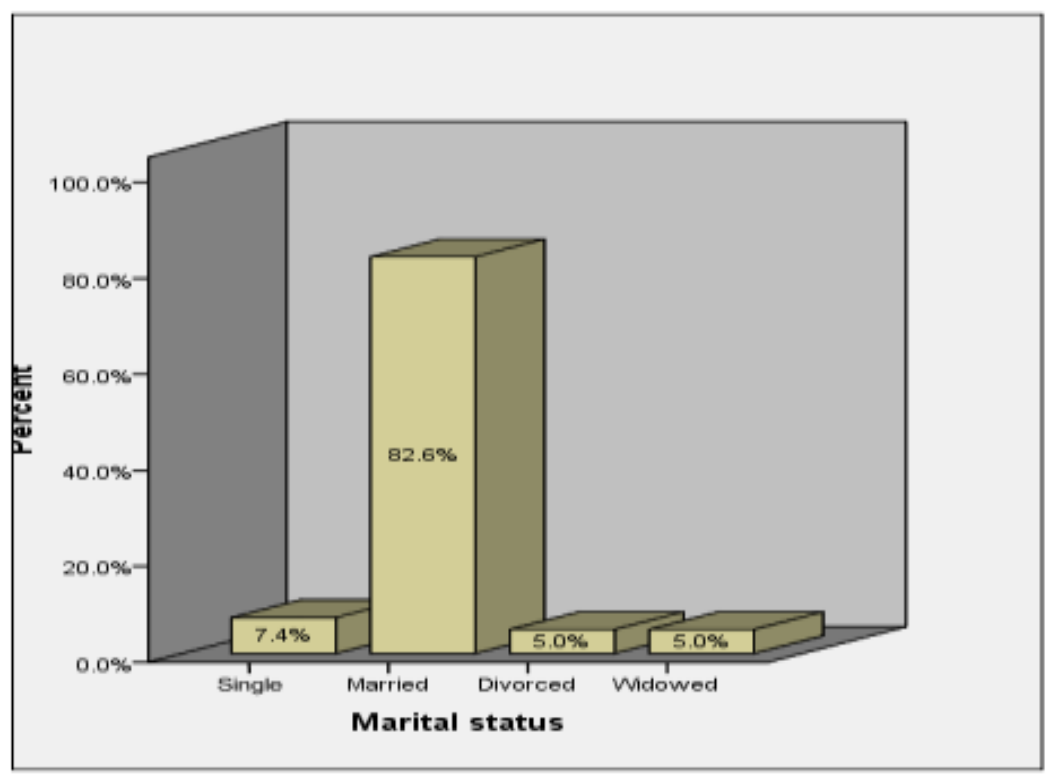

Figure 3: Marital status of the Respondent

\subsubsection{Highest Level of Academic Qualification}

The respondents were asked to indicate their highest level of academic qualification. Results presented in table 2 indicated that majority $(58.7 \%)$ of the respondents had attained masters' level, $39.3 \%$ had attained graduate level, $1.2 \%$ had attained college level while only $0.8 \%$ had attained doctorate level.

The results imply that majority of the respondents have attained sufficient education level to be able to handle managerial positions. This implies that the respondents have the potential to enhance deposit mobilization within Saccos. These findings support those of Hambrick and Mason (1994); Kariuki, Awino and Ogutu (2012,), who concluded that a high degree of education is associated with organizational success.

Table 2: Highest Level of Academic Qualifications

\begin{tabular}{lcc}
\hline Response & Frequency & Percent \\
\hline College & 2 & $1.2 \%$ \\
Graduate & 54 & $39.3 \%$ \\
Masters & 81 & $58.7 \%$ \\
Doctorate & 1 & $0.8 \%$ \\
Total & $\mathbf{1 3 8}$ & $\mathbf{1 0 0}$
\end{tabular}




\subsection{Descriptive Statistics Analysis}

Results revealed that majority of the respondents who were $60.9 \%(41.3 \%+19.6 \%)$ agreed with the statement that technological innovations attract interest from members to generate revenue streams and the sale of related products and services. 58\% agreed that technological innovations lead to more satisfied members hence higher economic returns. $60 \%$ agreed that technological banking solutions offer reduced member support costs as well as revenue growth. Further, $60.9 \%$ agreed that innovative, personalized mobile services also assist Saccos to attract and retain members.

In addition, $60.9 \%$ of the respondents agreed that technology adoption should be a top priority for Sacco management. 58\% agreed that reports produced by our information systems are accurate and reliable. $62.3 \%$ agreed that computerization has improved loans disbursement and recovery while $66 \%$ agreed that members' issues and statement requests are responded to promptly. The overall mean of the responses was 3.71 which indicated that majority of the respondents agreed to the statement of the questionnaire.

Additionally, the standard deviation of 1.11 indicated that the responses were varied. The results herein implied that Saccos recognize the role of technological adoption in enhancing performance. 
Table 3: Technological Adoption Strategy

\begin{tabular}{|c|c|c|c|c|c|c|c|}
\hline Statements & SD & D & $\mathbf{N}$ & $\mathbf{A}$ & SA & $\mathbf{M}$ & $\begin{array}{l}\text { Std. } \\
\text { Dev }\end{array}$ \\
\hline $\begin{array}{l}\text { Technological } \\
\text { innovations attract } \\
\text { interest from members to } \\
\text { generate revenue streams } \\
\text { and the sale of related } \\
\text { products and services }\end{array}$ & $0.70 \%$ & $16.70 \%$ & $21.70 \%$ & $41.30 \%$ & $19.60 \%$ & 3.62 & 1.01 \\
\hline $\begin{array}{l}\text { Technological } \\
\text { innovations lead to more } \\
\text { satisfied members hence } \\
\text { higher economic returns }\end{array}$ & $3.60 \%$ & $18.10 \%$ & $20.30 \%$ & $25.40 \%$ & $32.60 \%$ & 3.65 & 1.21 \\
\hline $\begin{array}{l}\text { Technological banking } \\
\text { solutions offer reduced } \\
\text { member support costs as } \\
\text { well as revenue growth }\end{array}$ & $1.40 \%$ & $16.70 \%$ & $18.80 \%$ & $35.50 \%$ & $27.50 \%$ & 3.71 & 1.09 \\
\hline $\begin{array}{l}\text { Innovative, personalized } \\
\text { mobile services also assis } \\
\text { Saccos to attract and } \\
\text { retain members }\end{array}$ & $2.20 \%$ & $15.90 \%$ & $21.00 \%$ & $16.70 \%$ & $44.20 \%$ & 3.85 & 1.21 \\
\hline $\begin{array}{l}\text { Technology adoption } \\
\text { should be a top priority } \\
\text { for Sacco management }\end{array}$ & $1.40 \%$ & $17.40 \%$ & $20.30 \%$ & $29.70 \%$ & $31.20 \%$ & 3.72 & 1.13 \\
\hline $\begin{array}{l}\text { Reports produced by our } \\
\text { information systems are } \\
\text { accurate and reliable }\end{array}$ & $2.90 \%$ & $19.60 \%$ & $19.60 \%$ & $32.60 \%$ & $25.40 \%$ & 3.58 & 1.15 \\
\hline $\begin{array}{l}\text { Computerization has } \\
\text { improved loans } \\
\text { disbursement and } \\
\text { recovery }\end{array}$ & $1.40 \%$ & $16.70 \%$ & $19.60 \%$ & $38.40 \%$ & $23.90 \%$ & 3.67 & 1.06 \\
\hline $\begin{array}{l}\text { Members issues and } \\
\text { statement requests are } \\
\text { responded to promptly }\end{array}$ & $0.70 \%$ & $16.70 \%$ & $16.70 \%$ & $29.00 \%$ & $37.00 \%$ & 3.85 & 1.12 \\
\hline Average & & & & & & 3.71 & 1.11 \\
\hline
\end{tabular}

Further, the respondents were asked to indicate the extent to which various technological innovations adopted by the Sacco affect its performance. Results presented in Table 4 revealed that $39.9 \%$ of the respondents rated the effect of technological innovations on performance to a very great extent, $30.4 \%$ to a great extent and $29.7 \%$ to a moderate extent. This implies that technological innovations adopted by the Saccos influences their performance. 
Table 4: Effect of Technological Innovations

\begin{tabular}{lcc}
\hline Response & Frequency & Percent \\
\hline Very great extent & 41 & 29.7 \\
To a great extent & 42 & 30.4 \\
Moderate extent & 55 & 39.9 \\
\hline Total & $\mathbf{1 3 8}$ & $\mathbf{1 0 0}$ \\
\hline
\end{tabular}

\subsection{Factor Analysis on Technological Adoption Strategy}

Factor analysis was used to summarize data to be more manageable without losing any important information and therefore making it easier to test hypothesis (Field, 2009). According to Kaiser (1974), factor loading values that are greater than 0.4 should be accepted and values below 0.4 should lead to collection of more data to help researcher to determine the values to include. Values between 0.5 and 0.7 are mediocre, values between 0.7 and 0.8 are good, values between 0.8 and 0.9 are great, and values above 0.9 are superb. The study therefore used sub constructs with values of 0.4 and above and dropped those with the values below 0.4 .

Results presented in Table 5 shows the set of sub variables under the variable technological adoption strategy that had factor loadings. All the sub variables except one had values more than 0.4 and therefore they were accepted.

Table 5: Factor loading for the Variable Technological Adoption Strategy

\begin{tabular}{lr} 
Sub-Constructs & Loading \\
\hline Technological innovations attract interest from members to generate revenue & \\
streams and the sale of related products and services & 0.496 \\
$\begin{array}{l}\text { Technological innovations lead to more satisfied members hence higher } \\
\text { economic returns }\end{array}$ & 0.195 \\
$\begin{array}{l}\text { Technological banking solutions offer reduced member support costs as well as } \\
\text { revenue growth }\end{array}$ & 0.516 \\
Innovative, personalized mobile services also assist Saccos to attract and retain & 0.482 \\
members & 0.423 \\
Technology adoption should be a top priority for Sacco management & 0.482 \\
Reports produced by our information systems are accurate and reliable & 0.68 \\
Computerization has improved loans disbursement and recovery & 0.512 \\
Members issues and statement requests are responded to promptly &
\end{tabular}




\subsection{Correlation Analysis}

Results presented in Table 6 indicate the correlation analysis between technological adoption strategy and performance of Saccos. The correlation results revealed that there was a positive and a significant association between technological adoption strategy and performance of Saccos $(r=0.788, p=0.000)$. This implies that technological adoption strategy and performance of Saccos change in the same direction.

The findings agree with those of Banson, Sey and Sakoe (2015) who found that mobile deposit as a way of deposit mobilization through mobile banking has proven to be very effective means of mobilizing deposit compared to the traditional way of deposit mobilization.

Table 6: Correlation Matrix

\begin{tabular}{|c|c|c|c|}
\hline & & Performance & Marketing Strategy \\
\hline \multirow[t]{2}{*}{ Performance } & Pearson Correlation & 1.000 & \\
\hline & Sig. (2-tailed) & & \\
\hline \multirow[t]{2}{*}{ Marketing Strategy } & Pearson Correlation & $.788 * *$ & 1.000 \\
\hline & Sig. (2-tailed) & 0.000 & \\
\hline
\end{tabular}

\subsection{Relationship between Technological Adoption Strategy Constructs and Performance of Saccos}

The results presented in table 7 present the regression model used in explaining the study phenomena. The findings reveal that computerization of processes; innovation capability and internet facility explained $55.8 \%$ of performance of Saccos in Kenya. This was supported by coefficient of determination also known as the $\mathrm{R}$ square of 55.8\%. This means that technological adoption strategy constructs explain $55.8 \%$ of total variations in the dependent variable.

Further, results indicate that the overall model was statistically significant as supported by a $\mathrm{p}$ value of 0.000 . This implies computerization of processes; innovation capability and internet facility are good predictors of performance of Saccos as supported by an F statistic of 56.429 and the reported $\mathrm{p}$ value $(0.000)$ which was less than the conventional probability of 0.05 significance level. 
Table 7: Regression Model

\begin{tabular}{lcccc}
\hline ROA & Coef. & Std. Err & $\mathbf{t}$ & $\mathbf{P}>|\mathbf{z}|$ \\
\hline Computerization of processes & .133 & .051 & 2.589 & .011 \\
Innovation capability & .209 & .040 & 5.248 & .000 \\
Internet facility & .111 & .082 & 1.340 & .035 \\
Cons & 2.477 & .112 & 22.073 & .000 \\
$\mathrm{R}^{2}$ & 0.558 & & & \\
F-statistics & 56.429 & & & \\
P value & 0.000 & & & \\
\hline
\end{tabular}

The specific model was;

Firm Performance $=2.477+0.133$ Computerization of processes +0.209 Innovation capability +0.111 Internet facility

Based on the beta coefficients, it is possible to rank the constructs as to which best explains the performance of Saccos in Kenya. From the results in Table 5, innovation capability ( $\beta=0.209)$ best explains performance, followed by computerization of processes $(\beta=0.133)$ and then internet facility $(\beta=0.111)$.

\subsection{Relationship between Joint Technological Adoption Strategy Constructs and Performance of Saccos}

The results presented in table 8 present the fitness of model used of the regression model in explaining the study phenomena. The findings reveal that jointly, technological adoption strategy constructs explained $62.1 \%$ of the performance of Saccos in Kenya. This means technological adoption strategy explains $62.1 \%$ of the total variations in the dependent variable (Performance of Saccos).

Table 8: Model Fitness

\begin{tabular}{lc}
\hline Indicator & Coefficient \\
\hline $\mathrm{R}$ & 0.788 \\
R Square & $\mathbf{0 . 6 2 1}$ \\
Adjusted R Square & 0.618 \\
Std. Error of the Estimate & 0.3003608 \\
\hline
\end{tabular}

Table 9 provides the results on the analysis of the variance (ANOVA). The results indicate that the overall model was statistically significant as supported by a $p$ value of 0.000 . This was supported by an F statistic of 222.728 and the reported p value $(0.000)$ which was less than the conventional probability of 0.05 significance level. The results imply that technological adoption strategy is a good predictor of performance. 
Table 9: Analysis of Variance

\begin{tabular}{|c|c|c|c|c|c|}
\hline Indicator & Sum of Squares & Df & Mean Square & $\mathbf{F}$ & Sig. \\
\hline Regression & 20.094 & 1 & 20.094 & 222.728 & $.000^{\mathrm{b}}$ \\
\hline Residual & 12.269 & 136 & .090 & & \\
\hline Total & 32.363 & 137 & & & \\
\hline
\end{tabular}

The table 10 presents the regression of coefficients results. The findings show that there is a positive and significant relationship between technological adoption strategy and performance of Saccos in Kenya as supported by a p value of 0.000 and a beta coefficient of (0.896). This implies that an increase in technological adoption strategy by a unit will improve the performance of deposit taking Saccos by 0.896 units.

The findings support those of Ahoya (2015) who established that technology innovations, process innovations and market innovations had a positive and significant effect on performance of Kenya Commercial Bank Ltd

Table 10: Regression of Coefficients

\begin{tabular}{lrrrr}
\hline & B & Std. Error & t & Sig. \\
\hline (Constant) & .361 & .224 & 1.614 & .109 \\
Technological adoption Strategy & .896 & .060 & 14.924 & .000 \\
\hline
\end{tabular}

The specific model;

$\mathrm{Y}=\beta_{0}+\beta_{1} \mathrm{X}_{3}+\mathrm{e}$

Performance $=0.361+0.896$ Technological Adoption Strategy

\subsection{Hypothesis Testing}

The hypothesis was tested by using the ordinary least square regression. The acceptance/rejection criteria was that, if the calculated $t$ statistic was greater than the critical $t$ statistics (1.96), the $\mathrm{H}_{0}$ is rejected but if it less than 1.96, the $\mathrm{H}_{0}$ fails to be rejected, The null hypothesis was that technological adoption strategy does not have any significant effect on the Performance of SACCOs in Kenya.

Results in Table 10 show that the calculated t statistic (14.924) was greater than the critical $t$ statistics (1.96). This indicated that the null hypothesis was rejected hence technological adoption strategy has a significant effect on the Performance of SACCOs. 


\subsection{SUMMARY, CONCLUSION AND RECOMMENDATIONS}

\subsection{Summary of Findings}

Results revealed that technological innovations attract interest from members to generate revenue streams and the sale of related products and services. Also, technological innovations lead to more satisfied members hence higher economic returns. Further, technological banking solutions offer reduced member support costs as well as revenue growth. Additionally, innovative, personalized mobile services assist Saccos to attract and retain members and that technology adoption should be a top priority for Sacco management.

Based on the beta coefficients, innovation capability was ranked first, computerization of processes second and internet facility third. This implied that innovation capability best explains firm performance, followed by computerization of processes and lastly internet facility.

Correlation analysis showed that technological adoption strategy and performance of Saccos are positively and significantly associated. Regression analysis indicated that technological adoption strategy has a positive and significant effect on performance of Saccos in Kenya. The hypotheses results indicated that there is a significant relationship between technological adoption strategy and performance of Saccos in Kenya.

\subsection{Conclusion}

Based on the findings the study concluded that technological adoption strategy affects the performance of Saccos in Kenya.The univariate regression results. Further, the overall regression results revealed that technological adoption strategy influenced the performance of Saccos 0.464units. This shows that the individual influence of technological adoption strategy on the performance of Saccos is more than the corporate influence (all the deposit mobilization strategies).

\subsection{Recommendation}

From the study findings, it was recommended that Saccos should lay out procedures and strategies such as product innovation, market innovation, technological innovation and process innovation so as to enhance their penetration in the market. Further, the study recommended the need for the firms to invest in technological advancement by equipping their staff with technical skills and also providing them with the necessary facilities.

\subsection{Suggestion for further Studies}

The study sought to establish the effects of technological adoption strategy on the performance of savings and credit cooperative societies and therefore an area for further studies could consider the influence of technological adoption strategy on the performance in Banks or Insurance Firms and or on larger firms like manufacturing firms for the purpose of making a comparison of the findings with those of the current study. 


\section{REFERENCES}

Adam, C. S., Collier, P., \& Ndulu, B. (Eds.). (2016). Tanzania: The Path to Prosperity. Oxford University Press.

Ademba, C. (2012). The scope of board accountability in financial co-operatives. 2nd Annual Financial Co-operatives Indaba, Durban. Retrieved from African Confederation of Cooperative Savings \& Credit Associations Website, http://www. accosca. org.

Banson, F. A. K., Sey, E., \& Sakoe, J. (2012). The Role of Mobile Deposit in Deposit Mobilization in Ghana. Asian Journal of Business and Management Sciences, 1-18.

Cheruiyot, T. K., Kimeli, C. M., \& Ogendo, S. M. (2012). Effect of Savings and Credit Cooperative Societies Strategies on Member's Savings Mobilization in Nairobi, Kenya. International Journal of Business and Commerce, 1(11), 40-63.

Cifuentes, M. (2002). Institutional Preconditions: Testing Readiness and Achieving Sustainability. Striking the Balance in Microfinance: A Practical Guide to Mobilizing Savings.

Cook, M. L., \& Chaddad, F. R. (2004). Redesigning cooperative boundaries: The emergence of new models. American Journal of Agricultural Economics, 86(5), 1249-1253.

Creswell, J. W. (1994). Research design: Qualitative \& quantitative approaches. Sage Publications, Inc.

Gallagher, K. P., Kaiser, K. M., Simon, J. C., Beath, C. M., \& Goles, T. (2010). The requisite variety of skills for IT professionals. Communications of the ACM, 53(6), 144-148.

Griliches, Z., \& Mason, W. M. (1972). Education, income, and ability. Journal of political Economy, 80(3, Part 2), S74-S103.

Hesse, H., \& Cihak, M. (2007). Cooperative banks and financial stability. International Monetary Fund.

Kamaamia, A. T. (2016). The Effect of Organizational Culture on Organizational Performance: A Case of Kenya School of Monetary Studies (Ksms) (Doctoral dissertation, United States International University-Africa).

Kariuki, P. M., Awino, Z. B., \& Ogutu, M. (2011). Effect of firm level factors, firm strategy, business environment on firm performance. Business Environment Journal, 1-27.

Kumar, V., Venkatesan, R., \& Reinartz, W. (2008). Performance implications of adopting a customer-focused sales campaign. Journal of Marketing, 72(5), 50-68.

Maina, R. W., Nyandemo, S. M., \& Kioko, U. (2016). Does Composition of Public Expenditure affect Economic growth? Evidence from Kenya. International Journal of Economics, 1(1), 61-78. 
Mandal, B., \& Mistri, B. Socio-Economic Status of Aged People at Dewli and Getugachhi Gram Panchayat in Chakdaha CD Block, Nadia District, West Bengal.

Mutegi, F. K. (2018). Role of Innovation Strategy on Insurance Penetration in Kenya (Doctoral dissertation, COHRED-JKUAT).

Nyoike, E. W., Ngugi, P. K., \& Muturi, W. (2017). The influence of creativity on performance of Small and Medium Manufacturing enterprises in Kenya. European Journal of Business Management, 5(9), 15-39.

Olando, C. O. (2012). An Assessment of financial practice as a determinant of growth of Savings and Credit Co-operative Societies wealth in Kenya: The case of Meru County (Doctoral dissertation, Doctoral Thesis, Kenyatta University, Kenya).

Olando, C. O., Jagongo, A. O., \& Mbewa, M. O. (2013). The contribution of SACCO financial stewardship to growth of SACCOS in Kenya.

Rogers, E. M., \& Shoemaker, F. F. (1971). Communication of Innovations; A Cross-Cultural Approach.

Smith, G. D., Ben-Shlomo, Y., \& Hart, C. (1999). Re:"Use of census-based aggregate variables to proxy for socioeconomic group: evidence from national samples”. American Journal of Epidemiology, 150(9), 996-997.

Tavassoli, S., \& Karlsson, C. (2015). Persistence of various types of innovation analyzed and explained. Research Policy, 44(10), 1887-1901.

Zhang, J., Di Benedetto, C. A., \& Hoenig, S. (2009). Product development strategy, product innovation performance, and the mediating role of knowledge utilization: evidence from subsidiaries in China. Journal of International Marketing, 17(2), 42-58. 